\title{
PERJALANAN WACANA JOKOWI DALAM PENCALONANNYA SEBAGAI KANDIDAT PRESIDEN 2019-2024
}

\author{
Redi Panuju \\ Staf Pengajar Fakultas Ilmu Komunikasi Universitas dr Soetomo \\ Email: redi.panuju@Unitomo.ac.id, redipanuju@gmail.com
}

\begin{abstract}
ABSTRAK
Artikel ini mengkaji penggunaan wacana komunisme yang kerapkali dijadikan issu untuk merepresentasikan keberadaan individu, kelompok maupun institusi tertentu di Indonesia. Wacana digunakan oleh pihak pihak tertentu sebagai cara mengkomunikasi maksud untuk menarik perhatian, membentuk pencitraan, membelah opini publik, dan pada akhirnya sebagai saluran membangun letimasi politik. Pada akhir bulan September 2017 wacana komunisme sebagai bahaya laten bagi Negara kesatuan Republik Indonesia (NKRI) merebak kembali melalui instruksi Panglima TNI Jendral Gatot Nurmantyo kepada jajaran TNI untuk memutar kembali film "G.30 S/PKI". Instruksi Panglima TNI tersebut menimbulkan pro-kontra di masyarakat di luar internal TNI. Melalui analisis wacana model Althusser dan Faucoult akan dapat dikontruksi komunikasi politik yang terjadi di level individu maupun institusi berkaitan dengan ajang pemilu tahun 2019.

Kajian ini dapat memberikan gambaran awal dan umum tentang issu issu yang digunakan sebagai instrument politik dalam kontestasi politik tahun 2019. Issu bahaya laten komunisme akan merecovery kelompok masa lalu yang dilabeling pada masa Orde Baru dan sebaliknya mereposisi kelompok Orde Baru yang dituduh mengaburkan sejarah dan akan muncul kelompok baru sebagai pendulum issu terdebut.
\end{abstract}

Kata Kunci : Komunisme, Legitimasi, produksi wacana, reproduksi wacana, Pilpres 2019

\section{A. PENDAHULUAN}

Perjalanan Presiden Joko Widodo sampai akhirnya memilih Prof Dr KH Ma'ruf Amin sebagai calon Wakil Presiden dalam Pilpres 2019 melalui liku liku wacana politik yang cukup panjang. Mulai dari issu komunisme, radikalisme, Kebencian publik berbasis agama, hingga ketidak berdayaan Jokowi menghadapi kekuatan modal asingkhsusnya modal dari China.

Komunikasi politik Jokowi tiga tahun terakhir banyak dilakukan dengan turun ke bawah serta ekspose media yang intens, menonjolkan visi nasionalisme dengan membendung wacana keagamaan. Analisis berdasarkan terori citra dan teori opini public yang dilakukan Panuju (2017, Vol 6 No2) menujukkan bahwa citra yang dibangun Jokowi sangat kuat pada citra kini, citra keinginan (visi), dan citra penampilan. Sementara Jokowi lemah pada citra cermin dan citra koorporasi.
Karena itu, semua wacana direspons baik sebagai produksi wacana maupun reproduksi wacana. Salah satu wacana yang secara terus menerus di produksi dan direproduksi dari masa Orde Baru hingga sekarang adalah wacana tentang PKI atau komunisme. Issu yang dimunculkan adalah bahwa PKI merupakan bahaya laten bangsa, yang anti Pancasila, anti NKRI, dan anti Pluralisme. Issu Komunisme memiliki nilai yang tinggi dalam komunikasi (information values) karena mengandung makna historis yang traumatik bagi bangsa Indonesia. Terutama dengan peristiwa gerakan PKI pada tanggal 30 September 1965 yang menimbulkan tragedi (pembunuhan) baik korbannya dari kalangan militer (angkatan Darat), masyarakat sipil, maupun anggota PKI itu sendiri.

Wacana bahaya ideologi komunis memiliki nilai informasi yang tinggi. Nilai komunikasi (information values) merupakan 
konsep yang menganalogikan dengan nilai berita (news values) dalam jurnalistik, yakni informasi yang mempunyai daya tarik magnitude tinggi, sehingga khalayak menaruh perhatian lebih disbanding dengan issu yang lain. Issu bahaya laten komunisme menjadi menarik perhatian disamping karena issunya bersifat mencekam (traumatik) juga diperkuat oleh gerakan gerakan politik status quo pada tahun 2017 yang mengintrodusir "radikalisme" bagai jargon politik pemerintahan Jokowi untuk melebaling atau menstigma lawan lawan politiknya. Komunisme sendiri sejak awal sudah dilabeling sebagai kelompok radikalis atau mengembangkan paham paham yang radikal. Ketika menulis tentang sejarah Semaoen Pers Bumi Putra dan Radikalisme, Yuliati (2000: 8-11) mendeskriditkan dengan lugas seorang Samaoen, redaktur Sinar Djaya dan Sinar Hindia pada tahun1914- 1917, yang membawa gaya jurnalistik menjadi radikal setelah Samaoen bergabung dengan ISDV (Indische Sociaal Democratische Vereeniging) sebuah organisasi pada masa Kolonial yang berbau paham komunisme. Untuk seterusnya gerakan komunisme dianggap radikalis oleh pemerintahan Hindia Belanda. Dalam konteks wacana "radikalisme", digunakan secara bersama sama diantara dua kubu untuk menstigmatisasi satu sama lain.

Kubu Jokowi distigma bersinggungan dengan gerakan PKI, misalnya oleh Bambang Tri Mulyono yang menulis buku "Jokowi Undercover". Penulisnya sendiri telah divonis penjara 3 tahun oleh Pengadilan Negeri Blora Jawa Tengah (https://news.detik.com/berita/d-3514323/ michael-bimo-terbukti-buku-jokowiundercover-isinya-fitnah). Jokowi sendiri beraksi keras dengan membantah issu tersebut dan bahkan dengan menggunakan diksi yang mengancam (coercive), yakni dengan kata kata : "Kalau PKI Nonggol, Gebuk saja!" (http://nasional.kompas.com/ $\mathrm{read} / 2017 / 05 / 17 / 16433321 /$ jokowi.kalau. pki.nongol.gebuk.saja )

Sangat mungkin, pihak Jokowi menengarai yang menyebarkan atau menggunakan issu tersebut dari lawan lawan politiknya yang secara katagoris masuk dalam kalangan "tengah-kanan", yakni kalangan nasionalis tengah yang berhimpitan dengan islam Kanan. Karena itu, issu radikalisme disublimasikan bukan hanya "komunisme" tetapi dengan anti tesis paham agama trans-nasional. Salah satunya adalah kelompok HTI (Hizbut Tahrir Indonesia). Untuk meyakinkan hal tersebut bahkan Pemerintah mengeluarkan Peraturan Pemerintah Penganti Undang Undang (Perpu) tentang Ormas (Perpu no 2 tahun 2017). Dengan perpu tersebutlah pemerintah membubarkan organisasi tersebut. Perpu disetujui oleh Sidang Paripurna Dewan Perwakilan Rakyat (DPR) pada 24 Oktober 2017, sehingga Perpu tersebut sah menjadi Undang Undang.

Mengangkat issu komunisme merupakan sebuah strategi mirip permainan "bola sodok". Di satu sisi membelah antara yang "pro" dengan alasan sejarah dengan yang "kontra" dengan alasan hak asasi manusia. Namun sebenarnya bola tidak hanya menuju ke kanan atau kekiri, tetapi bisa liar tidak menuju ke arah keduanya. Bola itu mendulum khalayak yang tidak mengetahui sejarah dan tidak pula bersimpaty pada politik aliran (etnis, agama, kedaerahan, dan lainnya). Siapa pun khalayak yang dibidik, ideologi komunisme masih menarik banyak kalangan, meskipun acapkali bersimbunyi pada rumpun sosialisme. Tema tema tentang kesenjangan ekonomi, gap antara kekuasaan dan rakyat, upah buruh, dan sejenisnya menjadi pintu masuk dalam menyebarkan ajaran Marxisme. Sementara itu, sejarah mencatat bahwa komunisme sempat eksis dalam perpolitikan Indonesia. Meminjam "teori meme" dari Richard Dawkwins, seorang guru besar ilmu heman di Universitas Oxforf dan penafsir teori Darwin di luar biologi, maka suatu penggandaan diri (gene) serta merta menjalankan evolusinya sendiri sesuai kepentingannya. Issu komunisme mengalami pengembangbiakan sesuai kepentingan politiknya pada suatu masa. Ada tiga hal sukses pengembangan diri, yaitu; usia sepanjang panjangnya, tersebar seluas luasnya, dan berketurunan 
seasli aslinya (Simbolon, 1998: xvi). Issu komunisme sebagai "meme" akan mencari jalannya sendiri untuk tetap ada dan berkembang biak.

Pada tahun 1955 dalam pemilu anggota konstituante, PKI menempati urutan keempat setelah Partai Nasional Indonesia (PNI) dengan jumlah suara 22,3\%; Masyumi 20,9\%; NU 18,4\% dan PKI 16,4\%. Bila dikonversi menjadi suara pemilih, maka jumlahnya relatif banyak. (Liddle, 1992:184). Itu sebabnya simpatisan komunisme mesikipun dianggap sudah mati secara institutional karena telah dilarang oleh TAP MPRS No.XXV/1966, namun gene komunisme masih tetap berkembang, maka mereka tetap menarik untuk diperebutkan.

Sebagai wacana, komunisme dikonstruksi sebagai pesan tertentu sesuai dengan kepentingan masing masing. Mengikuti pendapat Althusser, penyebar luasan wacana merepresentasikan kontestasi kekuatan politik lembaga (sosial dan politik). Representasi kekuatan politik sekaligus mengoneksikan media utama (media massa) maupun media alternatif (online). Di Indonesia, media massa (televisi dan cetak) dan internet masih dianggap penting sebagai sarana komunikasi politik. Deddy Mulyana (2014:22) meramal pada masa depan televisi, surat khabar, dan internet akan menjadi media utama dalam meningkatkan citra diri politisi, khususnya menjelang pemilihan legislative dan pemilihan kepala daerah. Maka pada masa mendatang biaya iklan pemilu tampaknya akan lebih besar lagi dari rp.2,5 triliun pada tahun 2009. Jan Van Dijk (2012:104105) menyebutkan media internet akan menjadi a tool for democracy, karena jumlah pemakai internet mengalami kelipatan sangat significant di masa depan, terutama karena informasi melalui internet dapat meningkatkan support pada pemerintahan dan kepercayaan publik pada penyelenggaraan pemilu yang dikelola melalui teknologi informasi.

Marcel Danesi (2002:251) menyatakan bahwa galaksi digital masa kini sebenarnya merupakan perluasan dari galaksi
Gutenberg. Danesi seakan hendak menyatakan bahwa abad digital sebenarnya meruapan perpanjangan dari gejala sebelumnya. Teknologi komunikasi dan informasi telah menyebabkan percepatan dalam produksi dan reproduksi serta defusinya. Tekanan pentingnya adalah di era digital ini, individu memiliki kebebasan yang besar bahkan absolut dalam partisipasi komunikasinya. Individu memiliki kesempatan untuk memproduksi pesan, memilih informasi, dan menyebarluaskannya sesuai dengan selektivitasnya sendiri. Dalam konteks pesan pesan politik, individu memiliki banyak alternative menggunakan media yang ada sesuai dengan alas an masing masing. Bila secara kebetulan kepemilikan media televisi berhimpitan dengan pelaku politik, karena pemiliki media sekaligus sebagai pengurus partai politik (Panuju 2015) menyebabkan public kurang percaya pada independensi sebagian media televisi atau menggeneralisirnya secara keseluruhan, maka sesuai logika Danesi, publik tidak menghentikan aktivitas produksi, reproduksi, dan distribusi (Share) issu tertentu, melainkan mengalihkannya melalui media internet. Karena itu banyak ditemukan konteks wacana yang tidak ada di media massa, kemudian justru menjadi viral di media sosial. Hal ini menjadi menarik dilihat dari konteks perebutan wacana dalam memperebutkan opini public antara Negara, media massa, dan civil society (Panuju 2002).

Karena itu issu komunisme selalu mengalami daur ulang dari masa ke masa yang digunakan untuk kompetisi ideologi. Khususnya pasca peristiwa 30 September 1966 dan pergantian dari regim Orde Lama ke Orde Baru, komunisme diwacanakan sebagai ideology yang berbahaya. Apalagi setelah siding MPRS menetapkan TAP MPRS No XXV/1966 yang membubarkan PKI dan melarang ideology Komunisme dan Marxisme berkembang di Indonesia, pemerintah Orde Baru memberlakukan sensor yang ketat terhadap media massa. Hal tersebut karena media massa telah terbukti memiliki kemampuan mengubah opini public dan bahkan menggerakkan 
massa. Daniel Dhakidae menulis "Negara dan Kecemburuannya Kepada Pers Sebuah Tinjauan Ideologis" (Ashadi Siregar, edt: p.11) didalamnya menyebutkan fakta bahwa pada tahun 1974 militer masuk ke dalam organisasi pers untuk menghabisi semua penerbitan PKI. Regim orba juga melakukan tautology dengan mengulang ulang wacana tentang bahaya laten komunisme, serta pentingnya komitmen menjalankan Pancasila secara murni dan konsekwen. Bahkan menurut Eriyanto (2000) untuk meneguhkan legitimasi kekuasaannya, Presiden Soeharto dalam setiap pidato kenegaraannya tanggal 16 Agustus sepanjang 32 tahun selalu mengulang ulang (tautologis) wacana komunisme sebagai bahaya laten bangsa Indonesia dan sebagai sebuah pelajaran sejarah tentang penyelewengan Pancasila. Pidato Presiden Soeharto tersebut ditayangkan langsung oleh seluruh stasiun televisi yang ada pada saat itu.

Begitupun setelah Orde Baru tumbang digantikan Orde Reformasi 1998, issu komunisme tetap menarik dilontarkan kalangan untuk membelah opini publik. Pada masa ini, media internet sudah sangat masif, sehingga issu bahaya komunisme terkonvergensi dengan media media personal ditangan warga masyarakat(celuler phone). Pernyataan Ketua Front Pembela Islam Habib Rizieq, sebagai contoh dimuat banyak media cetak dan on-line tentang bahaya bangkitnya komunisme. Pernyataan tersebut: JawaPos.com - Belakangan, isu bangkitnya Partai Komunis Indonesia (PKI) atau ideologi komunisme tumbuh subur. Klimaksnya, rusuh di kantor Lembaga Bantuan Hukum (LBH) Jakarta pada Senin (18/9) dini hari lalu. Penyebabnya, kegiatan Seminar 65 disebut sebagai momentum kebangkitan komunis (https://www.jawapos. $\mathrm{com} / \mathrm{read} / 2017 / 09 / 21 / 158440 / \mathrm{habib}$ rizieq-gerombolan-pki-panik-dan-kalapsiaga-revolusi)

Sebelumnya, Habieb Rizieq juga membuat wacana komunisme muncul ke permukaan karena pernyataannya tentang symbol "palu arit" yang nampak di beberapa pecahan uang kertas Republik Indonesia.

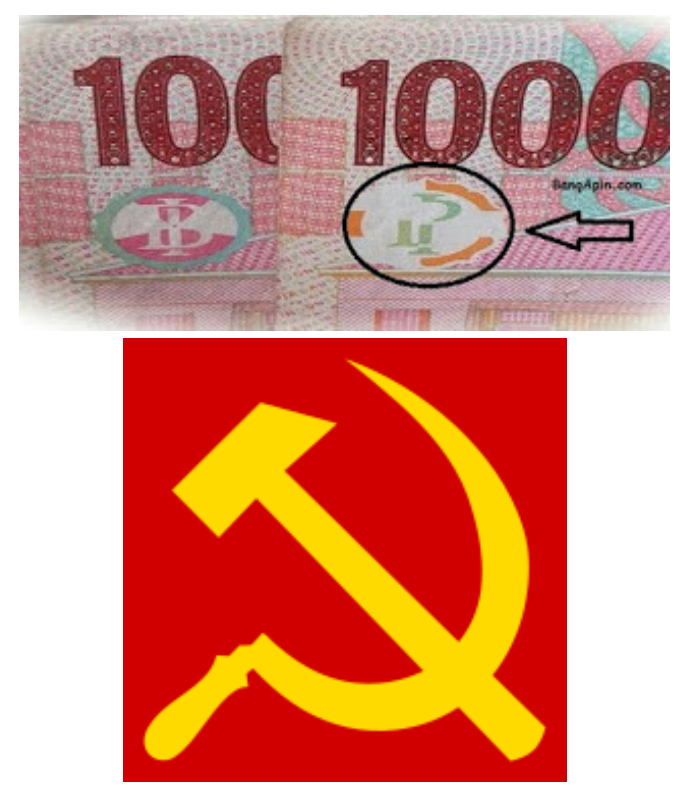

Gambar 1. Gambar mirip palu arit di uang kertas Rp100.000 dan simbol palu arit partai komunis

Sumber: www.laskarislam.com

Media on-line yang membahas masalah simbol palu arit kebanyakan media yang berafiliasi pada agama Islam. Salah satu web milik laskah islam.com misalnya meminta masyarakat untuk membandingkan antara gambar mirip palu arit di uang kertas Rp100.000 dengan simbol palu arit partai komunis (http://www.laskarislam.com/ t10467-simbol-pki-pada-uang-kertas)

Sepintas issu komunisme memang didulum oleh kelompok Islam tertentu untuk menujukkan representasi ideologisnya. Demikian juga dengan TNI dibawah komando Panglima Jendral Gatot Nurmantyo mengambil issu komunisme untuk menunjukkan posisi ideologisnya yang sama (bersebarangan dengan pendukung komunisme). Sementara Presiden Jokowi beserta tokoh tokoh partai yang lain cenderung mengambil posisi yang netral. Polarisasi kekuatan politik dengan instrument wacana komunisme inilah yang akan menjadi kajian artikel ini.

\section{B. METODE PENELITIAN}

Kajian ini menggunakan pendekatan kualitatif dengan data primer, yang diperoleh dengan cara mengobservasi 
teks wacana komunisme di media cetak maupun media on-line. Sumber sumber teks wacana komunisme diperoleh dari media cetak maupun media on-line yang terbit atau ekspose pada kurun waktu pertengahan tahun 2016 hingga akhir tahun 2018. Pada saat itu produksi teks tentang penodaan agama dan komunsime terjadi silih berganti. Sedangkan sumber teks atau objek yang diangkat oleh teks tersebut berasal dari subjek yang sama. Hal tersebut menunjukkan adanya keterkaitan antara produksi teks dan reproduksi teks yang bergantian menunjukkan kontestasi relasi kuasa. Dalam perspektif analisis relasi kuasa politik, hal tersebut menunjukkan gejala kontestasi merebut opini publik ( Panuju 2002: 1-24)

Teks akan dianalisis untuk menemukan kontruksi wacana komunisme sebagai sarana membelah afiliasi ideologis. Analisis pada tingkatan kontestasi ideology menggunakan konstruksi Louise Althusser, ideological state apparatus (ISA). Pada level konstruksi kuasa melalui teks menggunakan relasi kuasa Foucault, sedangkan pada level teks menggunakan pendekatan Norman Fairclough.

Althusser mengatakan bahwa seluruh lembagasosial dan politikterlibatpunyaandil dalam penyebaran ideology, dominasi, dan distribusi makna. Kajian semiotika struktural model Althusser ini dapat untuk mengetahui bekerjanya ideology dan hubungan kekuasaan antarstruktur masyarakat. Media sebagai bagian struktur yang berurusan dengan bahasa seringkali ditunjuk sebagai biang penyebar ideologi. Pada penelitian ini dapat dipahami penyebar luasan wacana komunisme memperlihatkan representasi kekuatan individu ataupun lembaga dalam kontestasi politik (Hermawan 2011: 256)

Analisis wacana model Fouclault menitik beratkan pada kekuasaan (power), merupakan kata kunci yang harus diperhatikan oleh peneliti discourse analysis. Kekuasaan menentukan dan mengkonstruksi adanya realitas realitas yang diciptakan secara subjektif untuk kepentingan dan tujuan power domination atau kekuasaan yang mendominasi. Focus analisis pada kekuatan kekuatan yang mengitari area wacana (Ida 2014:112)

Pendekatan Fairclough meliputi tiga tingkatan analisis, yaitu:teks, proses produksi dan penerima teks, dan konsteks sosial yang lebih besar. Fairclough juga menyarankan analisis terhadap blok bangunan identitas, baik identitas personal maupun lembaga. Sehingga teks akan merepresentasikan idealisasi dari suatu realitas tertentu yang membelah antara kelompok sendiri (self) dan kelompok yang berseberangan (other). Dengan demikian, mobilisasi dan peraturan yang mengikuti wacana menciptakan teks baru guna mengkontruksi realitas (Littlejohn 2009:222)

\section{KERANGKA KONSEP}

Banyak fenomena menunjukkan bahwa konflik disebabkan faktor sosiologis dan lingusitik. Dari persepektif Sosiologis konflik muncul dan menguat karena alasan alasan kesenjangan. Kaum Marxian misalnya, melihat konflik sebagai alasan memperjuangkan hak hak dan akses ekonomis sebagai warga Negara. Kesenjangan sosial ekonomi menjadi lahan penyemai tumbuh suburnya paham gerakan yang berbasis marxisme. Sebagian yang lain, misalnya merunut pemikiran Talcott Parson, melihat bahwa konflik merupakan implikasi dari upaya upaya sub system dalam system social yang sedang menyelesaikan perbedaan perbedaannya untuk mencapai tingkat keseimbangan (equilibrium) tertentu. Dalam upaya mencapai tingkat keseimbangan tersebut masing masing pihak berusaha melakukan adaptasi sampai tercapainya keadaan harmoni tertentu.

Sedangkan faktor linguistik mengambil peran memproduksi realitas sosiologis tersebut hingga merepresentasikan alasan alasan perbedaan yang ada dan mendistribusikan secara massif kepada warga Negara. Representasi realitas sosiologis inilah yang kemudian disebut sebagai "wacana" (discourse). Dalam perspektif komunikasi, pendistribuskan pendistribusian wacana merupakan upaya 
masing masing pihak (communicate) untuk membangun dan/atau mengubah opini publik. Opini public memiliki fungsi mengarahkan khalayak mempolarisasikan tuntutan dan dukungan (support and demands). Panuju (2002:11-23) menyebut opini publik sebagai instrument memainkan wacana untuk membentuk kesan kepedulian, keberpihakan, dan memperjuangkan (empaty) dan kemudian diharapkan menghasilkan simpaty atau sebaliknya mengarahkan khalayak untuk mengesankan (citra) pihak tertentu sebagai pihak yang tidak empaty sehingga menghasilkan respons antipati.

Pada level linguistik, konflik bekerja pada tataran wacana yang masing masing memproduksi dan mendistribisukan representasi sebagai pihak yang setuju dengan wacana tertentu (pro) dan sebagian menunjukkan pihak yang tidak setuju (kontra). Alasan alasan mengapa "setuju" dan "tidak setuju" acapkali bukan berdasarkan objektivitas, rasionalitas, ataupun faktualitas, melainkan cenderung berdasarkan subjektivitas. Karena itu, Althusser menandai konflik wacana sebagai reapresentasi individu atau institusi yang sedang konflik memperebutkan kekuasaan tertentu.

Konflik di tingkat wacana ini dianggap mengkawatirkan eksistensi pihak tertentu yang merasa terganggu pencitraannya, karena itu berusaha meredamnya dengan berbagai cara, baik menggunakan wacana maupun gerakan sosial tertentu. Pihak pihak tertentu yang merasa dirugikan dengan wacana tertentu akan menciptakan wacana yang bersifat berlawanan dengan isi wacana maupun dengan pernyataan pernyataan untuk meyakinkan khalayak bahwa wacana tersebut tidak benar.

Ada proses aksi dan reaksi dalam komunikasi, berupa produksi teks dan reproduksi. Bagi state aparatures produksi teks dilakukan sebagai cara mensosialisasikan ideologi kekuasaannya, agar masyarakat meningkat kepatuhannya (loyalitas) dan sekaligus terdorong partisipasinya. Produksi teks oleh kekuasaan ini direaksi berupa reproduksi teks yang sifatnya apriori, sehingga terjadilah diversifikasi teks. Dalam perspektif pemasaran politik, teks ini berfungsi sebagai semacam komoditas yang tersaji dengan baik di etalasi etalasi penjualan. Konsumen bisa menelaah, membandingkan, dan mengevaluasinya sebelum memutuskan untuk menerima, menolak, atau dalam kondisi diam (tidak mengambil sikap).

Issu komunisme merupakan wacana yang sangat sensitif bagi masyarakat karena sebagian masyarakat Indonesia pernah mengalami peristiwa yang mencekam pada tahun 1965, namun sebagian yang lain terutama mereka yang lahir pada tahun 80an hanya mengetahui peristiwa itu dari buku buku sejarah, film, dan diskusi diskusi baik di media massa maupun acara seminar. Mereka yang mendapatkan pengertian komunisme dari referensi mungkin terpengaruh namun bisa juga skeptis. Mereka yang skeptis ini mendapatkan referensi bahwa komunisme adalah ideologi dan keyakinan warga Negara terhadap ideologi merupakan hak asasi manusia. Karena itu, wacana komunisme memiliki potensi membelah opini publik secara simetris.

Pembelahan opini publik sekaligus mempolarisasikan para pendulum wacana komunisme untuk kepentingan pencitraan. Ada yang mewacanakan penolakan dan ada yang mendukung.

\section{PEMBAHASAN}

Meskipun komunisme sebagai ideologi di Indonesia sudah berakhir pada tahun 1966, namun sebagai wacana tetap diproduksi dan direproduksi. Artikel ini membatasi diri produksi dan reproduksi komunisme sebagai wacana pada kurun waktu 2016-2017 dengan pertimbangan karena pada 2 tahun ini wacana komunisme diproduksi dan direproduksi relatif banyak.

Pemberitaan tentang komunisme dalam pandangan (perspektif) analisis wacana bukan sekedar penyebar luasan fakta yang bertujuan informatif atau sekedar untuk diketahui oleh khalayak, melainkan mengandung maksud maksud tertentu 
bagi penyampainya. Penyampai di sini bisa media yang memanfaatkan issu tersebut tapi bisa juga pihak tertentu, baik individu maupun institusi. Bila tujuan penelitian ingin mengetahui keberpihakan media dalam menyiarkan issu tersebut, maka metode yang digunakan lazimnya analisis bingkai (framing analysis), sedangkan bila tujuannya untuk mengetahui issu digunakan oleh siapa dan untuk siapa, maka lazimnya menggunakan analisis wacana (discources analysis). Oleh karena penelitian ini membatasi diri pada penelitian analisis wacana, maka menghindari terlebih dahulu menggunakan analisis bingkai.

Sebagai wacana yang diproduksi dan direproduksi sejak Indonesia merdeka tahun 1945, wacana komunisme mengalami konteks yang berubah ubah. Sejarawan Taufik Abdullah (2012) mengisihkan dengan baik kisah perjalanan ideology Komunisme sebelum dan sesudah meletus meletusnya peristiwa 30 September 1965. Sebelum meletus peristiwa tersebut, ideologi komunisme yang diusung oleh Partai Komunis Indonesia (PKI) sempat menjadi tiga besar ideologi yang berkompetisi merebut hati rakyat, yakni ideologi komunisme, ideologi kapitalisme, dan militerisme. Pada masa masa pengaruh Soekarno mulai meredup, ada tanda tanda Soekarno dimusuhi Barat terutama Amerika Serikat. Soekarno membuat poros Jakarta- Peking-Moscow untuk melawan propaganda Amerika. Langkah Soekarno tersebut mendapat dukungan kalangan PKI.

Selanjutnya, Taufik Abdullah (2012) menyebut bahwa peristiwa 1965 itu mempunyai dampak sosial yang luar biasa dan melibatkan berbagaielemen masyarakat secara aktif. Tatanan, etika, dan norma dalam masyarakat menjadi rusak. Di bawah Orde Baru, secara filosofis komunisme sebagai ideologi juga mengalami pergeseran makna. Bukan lagi merupakan kumpulan idea tau mazhab filsafat saja, tetapi telah dipersempit menjadi kumpulan segala sesuatu yang bermakna buruk dan jahat.

Dengan kata lain, istilah komunisme mengalami pergeseran makna situasional, yang berkonotasi positif pada masa Orde Lama dan menjadi negative pada masa Orde Baru. Bagaimana setelah memasuki Masa Orde reformasi (pasca 1998)? Sudah barang tentu kesan positif dan negatif tersebut terbelah sesuai pengalaman masing masing. Bagi masyarakat yang pernah mengalami trauma terhadap komunisme cenderung resisten terhadap istilah komunisme. Prof Dr T Jacob (2004) menyebut komunisme itu sebagai "hantu komunisme". Seperti hantu, kata Jacob, adalah sulit dihalau. Bahan punya potensi untuk bangkit lagi. T. Jacob menyatakan :

"Hantu Komunisme bangkit kembali dan menggoda orang orang yang iman dan prinsipnya tidak ada atau tidak kuat. Dibayangkan kalau komunisme diizinkan untuk dibaca dan dipelajari, maka segala ideologi lain serta merta akan kalah. Kaum Komunis akan berkuasa dan membentuk Republik Demokrasi Rakyat menuju ditaktur proletariat." (Jacob 2004: 277)

Berbeda dengan yang memuja ideologi komunis, maka wacana komunisme dianggap sebagai sesuatu yang berkonotasi baik. Wacana yang dikembangkan adalah pelanggaran hak asasi manusia terhadap warga Negara yang dituduh terlibat gerakan G $30 \mathrm{~S} / \mathrm{PKI}$. Karena itu mereka butuh rehabilitasi (Denny JA 2006: 129). Kata rehabilitasi menunjukkan bahwa mereka adalah "korban". Mirip pemakai narkoba yang dianggap korban, maka solusinya "rehabilitasi".

\section{Produksi wacana}

Kajian ini dimulai dengan menghimpun upaya produksi komunisme dan reproduksi untuk mengetahui ymbol mengapa hal tersebut terjadi dan siapa ymbo yang mengambil peran dalam produksi dan reproduksi komunisme.

Produksi wacana komunisme mengemuka kembali setelah stagnan di masa pemerintahan Soeharto, ketika Gus Dur menjabat Presiden RI. Gus Dur mengatakan demikian: "Puluhan ribu atau mungkin ratusan ribu orang dipenjarakan 
karena dituduh 'terlibat' PKI. Banyak yang meninggal dunia dalam keadaan sangat menyedihkan, sedangkan yang masih hidup banyak yang tidak memiliki hak-hak politik sama sekali, termasuk hak memilih dalam pemilihan umum. Rumah-rumah dan harta benda mereka dirampas. Sementara, stigma mereka adalah pengkhianat bangsa tetap melekat pada diri mereka hingga saat ini," (www.news.detik.com/kolom/3663373/ rekonsiliasi-1965-belajar-dari-gus-dur ) .

Setelah itu reproduksi dilanjutkan dalam SIMPOSIUM Nasional Peristiwa G30S/PKI 1965 yang digelar dua hari di Hotel Arya Duta Jakarta merekomendasikan penyelesaian kasus pelanggaran HAM berat ymbol 1965 melalui jalur rekonsiliasi. Tokoh yang berperan dalam symposium ini adalah Luhut Binsar Panjaitan yang kala itu menjabat sebagai Menko Hukum dan HAM dan Gubernur Lemhanas kala itu Agus Widjoyo (http://www.mediaindonesia.com/ news/read/41277/rekonsiliasi-jalan-terbaikkasus-1965/2016-04-19).

Selanjutnya, tokoh tokoh yang mengaku leluhurnya menjadi korban HAM tahun 1965 tersebut bergabung dalam Yayasan Penelitian Korban Pembunuhan (YPKP). YPKP melakukan investigasi di beberapa daerah dan menemukan kuburan masal yang diduga sebagai kuburan orang orang yang dituduh anggota atau simpatisan PKI. Konon upaya pencarian fata tersebut sempat diintimidasi beberapa pihak. Dan Luhut Binsar Panjaitan membela mereka dengan diksi :" angan diganggulah pekerjaannya," kata Luhut menanggapi pertanyaan wartawan di Jakarta,Senin(09/05) siang (http://www.bbc.com/indonesia/berita_ indonesia/2016/05/160509_indonesia_ tim_kuburanmassal65). Upaya ini menurut Binsan mendapat dukungan dari Presiden Jokowi dengan narasi sebagai berikut: Menteri Koordinator Politik Hukum dan Keamanan Luhut Binsar Pandjaitan menyatakan Presiden Joko Widodo memerintahkannya untuk mencari kuburan ymbolkorban peristiwa 1965 danlanjutannya. (http://www.bbc.com/indonesia/berita_ indonesia/2016/04/160425_indonesia_ luhut_pki ).
Produksi wacana bukan hanya dibuat oleh orang Indonesia tetapi juga orang luar negeri, antara lain seorang Hakim Internasional People's Tribunal, menyatakan bahwa Negara Indonesia bersalah dan harus bertanggung jawab atas kejahatan terhadap nilai-nilai kemanusiaan.Hakim Ketua Zak Jacoob menyatakan, Pemerintah Indonesia harus minta maaf kepada para korban, penyintas, dan keluarga korban. Pemerintah juga didesak melakukan penyelidikan kejahatan terhadap kemanusiaan, sebagaimana tuntutan Komnas HAM dan Komnas Perempuan dalam laporannya. (http://nasional. kompas.com/read/2016/07/20/18215901/ indonesia.didesak.minta.maaf.dan. bertanggung.jawab.atas.kasus.1965)

\section{Reproduksi Wacana}

Produksi wacana tersebut di atas direproduksi secara bipolar, baik yang mendukung maupun yang menolak.

Kalangan yang menolak memaknai sebagai tanda tanda kebangkitan komunisme. FPI (Fron Pembela Islam) melalui Ketuanya Habieb Rizieq melihat tanda tanda yang paling mencolok adalah upaya terus menerus berbagai pihak yang menekan MPR RI untuk mencabut TAP MPRS No XXV/1966. (www.rappler.com/ indonesia/118365-tanda-kebangkitankomunisme-fpi)

Ratna Mufidah, ibu rumah tangga Aktivis HTI (sebelum dibubarkan) menulis demikian: Musuh ymbolt Islam bukan hanya kapitalisme yang saat ini diwakili Amerika sebagai Negara adidaya dunia, tetapi juga komunisme yang diwakili China dan menuju kebangkitannya untuk menguasai sebagian regional dunia (http://www.voa-islam.com/ read/world-analysis/2016/09/29/46451/ mewaspadai-bangkitnya-komunisme-diindonesia/\#sthash.AOZ8h4fB.dpbs)

Tokoh lain yang mereproduksi komunisme adalah Kiflan Zein. Kivlan merupakan purnawirawan jenderal bintang dua. Namanya wara-wiri pemberitaan media massa. Dia kerap menggelorakan bahaya laten kebangkitan Partai Komunis Indonesia 
(PKI) di era kepemimpinan Presiden Joko Widodo sekarang.Bagi Kivlan, Komunis bukan saja ancaman. Tapi sudah nyata hadir di tengah masyarakat. Berulang kali dia menyebut PKI sudah kembali terorgasasi dan memiliki markas (http://news.liputan6. $\mathrm{com} / \mathrm{read} / 3100590 /$ kivlan-zein-dan-isukebangkitan-pki)

Mendekati tanggal 30 September 2017, Panglima TNI Jendral Gatot Nurmantyo memerintahkan jajaran TNI menonton film G 30 S/PKI, dengan maksud agar diketaui generasi muda supaya tidak terprovokasi lagi. Perintah Panglima TNI yang semula ditujukan kepada jajarannya, ternyata disambut oleh masyarakat sipil dengan nonton bareng (nobar) film tersebut. Bahkan Presiden Jokowi ikut nonton bersama ratusan warga di Kota Bogor di Lapangan Tenis Makorem 061/ Suryakancana, Jumat (29/9/2017) malam (http://www.tribunnews. $\mathrm{com} /$ nasional/2017/09/30/nonton-barengdi-bogor-panglima-tni-jokowi-seriusnonton-film-g30spki-jadi-tak-sempatkomentar)
Reproduksi wacana komunisme yang bersifat membela umumnya dengan ymbol persoalan hak asasi manusia.

Ariel Haryanto menyatakan bahwa wacana komunisme selalu diproduksi dan direproduksi sebagai jelang pesta demokrasi. Dalam konteks itu dapat dipahami mengapa isu "bahaya komunis" kini kambuh kembali. Pemilu 2019 tidak bisa dibilang masih jauh. Apalagi Pemilihan Gubernur DKI Jakarta 2017 yang sudah memanas (https://www.cnnindonesia.com/ nasional/20160510094659-21-129620/ kapan-kambuhnya-bahaya-pki/). Ini sesuai dengan pandangan Althusser bahwa setiap orang dan lembaga sosial memiliki andil dalam menyebar luaskan ymbolt. Setiap individu dan lembaga social juga memiliki pandangan subjektifnya tentang fungsi ideologinya.

Bila disederhanakan, penyebar luasan ideology komunisme merepresentasikan kekuatan individu dan lembaga sebagai berikut:

Tabel 1. Representasi kekuatan Individu Penyebar luasan Wacana Komunisme

\begin{tabular}{lll}
\hline Jenis wacana & \multicolumn{1}{c}{ Individu } & \multicolumn{1}{c}{ Afiliasi } \\
\hline Bahaya Laten & Habieb Rizieq & FPI \\
& Joko Widodo & Presiden RI \\
& Gatot Nurmantyo & Panglima TNI \\
& Luhut Binsar Panjaitan & Menko Polkam \\
& Kivlan Zein & TNI, Partai Gerindra \\
& Ratna Mufidah & Ibu Rumah Tangga/HTI \\
& & \\
Hak Asasi Manusia & Ariel Haryanto & \\
& Zak Jacoob & Guru Besar, Akademisi \\
& & Hakim International \\
\cline { 2 - 2 } & Joko Widodo & Yayasan Penelitian Korban Massal \\
& Luhut Binsar Panjaitan & Presiden RI \\
& YLBHI Jakarta & Menkopolhukam \\
& Islam Kiri & PKM
\end{tabular}

Sumber : Analisis Teks Pemberitaan Media yang diolah Peneliti

Dalam penyebar luasan simbol komunisme, TNI dan kalangan Islam "kanan" sebagai lembaga yang cenderung resisten terhadap simbol tersebut dengan simbol yang berbeda. Bagi TNI, PKI merupakan sejarah kelam dimana keduanya saling berhadapan pada tahun 1965-1966 dan periode berikutnya pada masa regim Orde Baru. Sementara bagi "Islam kanan", resistensi disebabkan asumsi bahwa komunisme cenderung condong pada ateisme. Wacana komunisme menjadi alat 
pendulum legitimasi yang menarik bagi partai karena itu ada tiga katagori sikap partai terhadap wacana komunisme. Partai Gerindra dan Partai Keadilan Sejahtera bersikap resisten terhadap komunisme. Dengan demikian dua partai ini bias mendapatsimpaty dari kalangan Islam kanan dan masyarakat yang respek terhadap TNI. Sementara partai pendukung pemerintahan Jokowi cenderung bersikap hati hati dan memilih menghindari tema komunisme sebagai bahan diskusi, kecuali PDIP dan PKB yang melihat persoalan komunisme sebagai persoalan hak asasi manusia. Dengan begitu, bila wacana komunisme terus digulirkan hingga tahun 2019, maka masyarakat akan terbelah secara ideologis yakni koalisi antara Nasionalis TNI dan Islam Kanan berhadapan dengan koalisi nasionalisme tradisional dan Islam Kiri.

Sebagai representasi individual, peta wacana seperti di atas menunjukkan gejala yang menarik, yakni posisi empat orang tokoh; Pertama, posisi Presiden Joko Widodo, yang memperlihatkan berdiri di dua kaki. Posisi Jokowi seolah berada pada entitas yang menolak komunisme bila dilihat dari statemennya "Kalau Komunis nonggol saya yang nggebuk" dan "perilaku menonton bareng film G 30 S PKI". Namun bila dilihat dari dukungannya terhadap pencarian kuburan korban peristiwa 1965 seolah kakinya berada pada entitas pendukung komunisme.

Dalam hal ini, Goerge Gerbner dan Larry Gross membantu kita menganalisis peristiwa ini. Bagi Gerbner, apa yang disampaikan Joko Widodo tidak bisa disimpulkan bahwa dirinya berideologi ganda, disamping sebagai WNI yang Pancasilais juga komunis. Tudingan bahwa masa lalu Jokowi berkaitan dengan PKI sudah dibantah berkali kali. Lantas apa artinya? Gerbner menyatakan bahwa media massa (khususnya TV) merupakan alat dari orde yang telah mapan, berfungsi terutama untuk menyampaikan dan mempertahankan pola pola sosial. Ideologi adalah peta yang dapat dimengerti (Lull 1998: 8). Jokowi menggunakan issu komunisme sebagai perkakas untuk menghimpun khalayak representasinya. Ekspose yang demikian sebetulnya sekedar untuk tujuan publisitas, bagian dari pencitraan.

Kedua, Luhur Binsar Panjaitan. Tokoh ini memang sejak kontestasi presiden tahun 2014 merupakan loyalis Jokowi. Bahkan menjadi tim sukses yang cakap dalam menjalankan relasi media (media relations). Dalam beberapa kesampatan dirinya muncul dalam acara talk show di ymbolt dan berhasil menjelaskan secara rinci apa yang akan dilakukan Jokowi jika terpilih sebagai Presiden RI periode 2015-2019. Dalam kasus "Mama Minta Saham" yang menyeret nama Setya Novanto (Ketua DPR RI),Maroef Syamsoeddin dan pengusaha Reza Chalid pada akhir tahun 2015 misalnya, beredar transkrip pembicaraan mereka dimana Setya Novanto menyebut nama Luhut sebanyak 66 kali dan menempatkan Luhut sebagai "operator" pemikiran Jokowi. Paling tidak wacana tersebut menujukkan pengaruh Luhut Binsar Panjaitan dalam rulling elite Indonesia saat ini (https://news.detik. com/berita/d-3084683/beredar-transkriplengkap-pembicaraan-novanto-luhutdisebut-66-kali). Wajarlah bila pada akhir pemerintahan Jokowi-JK, Luhut menjadi "penyambung lidah" Jokowi. Dalam wacana pencarian kuburan ymbol korban kerusuhan tahun 1966 misalnya, Luhut meneruskan perintah Jokowi supaya pencarian korban kerusuhan tersebut dilanjutkan. Dengan demikian, mengikuti pemikiran Althusser, bahwa wacana merupakan representasi kekuatan politik tertentu, maka posisi Luhut menempel kepada Jokowi.

Ketiga, Gatot Nurmantyo, mirip dengan Jokowi bermain di dua kaki, namun bedanya Gatot meletakkan satu kaki ke Jokowi dan kaki yang lain ke komunitas Islam modern ("Islam Kanan"). Dalam wacana komunisme, Gatot terang-terangan (eksplisit) menyatakan permusuhannya dengan ideologi komunisme. Kedekatannya dengan Islam Kanan misalnya dapat ditunjukkan pada peristiwa-peristiwa beberapa kali Gatot menghadiri undangan Partai Keadilan Sejahtera (PKS). Hal tersebut membuat Presiden Jokowi mengeluarkan statemen agar TNI tidak berpolitik. Ketua 
Fraksi PKS, Jazuli Juwaini menilai, wajar saja Presiden Jokowi sebagai panglima tertinggi di TNI mengingatkan agar TNI tak masuk politik praktis. Meski begitu, ia menegaskan, Panglima TNI Jenderal Gatot Nurmantyo sama sekali tak bermanuver politik."Saya juga tidak melihat bahwa TNI bermanuver politik. Kalau seorang panglima diundang parpol ymbol itu bukan berarti bermanuver politik. Karena kita berbicara tentang bangsa dan ymbol, tentang Pancasila, NKRI," kata Jazuli di Gedung DPR, Jakarta, Kamis, 5 Oktober 2017 (http://www.viva. co.id/berita/politik/963637-pks-diundangparpol-bukan-berarti-gatot-berpolitik)
Melalui wacana komunisme terjadi kontestasi memperebutkan simpaty kepada Jokowi antara Gatot dan Binsar.

Keempat, Kivlan Zein seperti halnya Luhut adalah mantan Purnawiran TNI yang aktif di politik. Luhut berafiliasi ke PDI P sementara Kivlan ke Partai Gerindra. Kivlan memilih ekstrim menantang komunisme. Melihat wacananya itu Kivlan bakal membawa issu komunisme untuk politik identitas Partai Gerinda di masa depan.

Mengikuti pemikiran Althusser, ideologicalstate apparatus, pola penyebaran ideologi komunisme berimplikasi pada peta partai dan individu sebagai berikut:

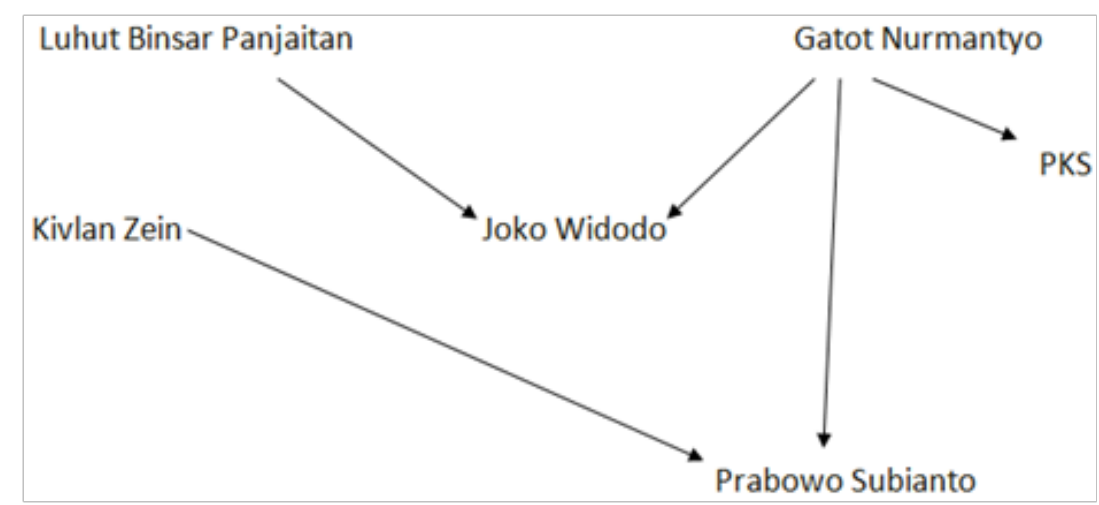

Diagram 1. Implikasi Reproduksi Wacana pada Relasi Kuasa Indovidu

Sumber: Olahan Peneliti

Pada gambar di atas nampak posisi Gatot memiliki tiga anak panah, satu ke Jokowi, satu ke Prabowo dan satu lagi ke PKS. Sangat mungkin, makna ke depannya, bila Jokowi memilih Luhut sebagai Calon Wapres pada Pilpres 2019, maka peluang Gatot untuk dipinang Prabowo sebagai Cawapres sangat besar. Namun bila dua duanya tidak mengambil, Gatot berpeluang maju sendiri sebagai Capres dari PKS. Wacana PKS akan mencalonkan Gatot sudah mengemuka melalui berita berikut ini : Sepak terjang Panglima TNI, Jenderal Gatot Nurmantyo, diamati dan menjadi perhatian partai politik. Partai Keadilan Sejahtera (PKS) bahkan sudah menyatakan bahwa Gatot berpotensi untuk didukung dalam Pilpres 2019 mendatang. (https://news.detik.com/ berita-jawa-tengah/d-3664561/menurutpks-jenderal-gatot-nurmantyo-caprespotensial-2019)
Namun diawal Agustus 2018, semua analisis ini di atas tidak mendapatkan bukti dalam realitas politik baik dari sisi kubu Jokowi maupun Prabowo. Dalam konteks ini dapat dimaknai, bahwa produksi wacana dan reproduksi wacana digunakan sebagai tesis memancing pihak lawan untuk mengambil keputusan. Tokoh tokoh yang sebelumnya masuk radar wacana Calon Wapres Jokowi seperti Muhaimin Iskandar, Luhut Binsar Panjaitan, Maupun Toto Karnavian tidak menjadi pertimbangan. Keputusan Jokowi memilih KH Ma'ruf Amin sebagai Calon Wapres tidak bisa menampik bahwa keputusan itu sebagai jawaban atas kekawatiran Jokowi terhadap masa Islam Kanan yang terbukti dapat menjungkir balikkan peta politik pada kontestasi Pilgun DKI Jakarta pada tahun sebelumnya. Sebagai Ketua MUI, saat itu Ma'ruf Amin terlibat dalam meyakinkan Hakim memutuskan 
Basuki Tjahya Purnama alias Ahok bersalah dalam kasus penodaan agama, karena itu dianggap dekat dengan lingkaran Islam Kanan yang dianggap berhaluan "keras", namun di sisi lain Ma'ruf Amin juga dianggap sosok yang dapat memobilisasi kalangan Nahdiyin (NU) karena posisi Amin sebagai Rois Am organisasi Islam moderat tersebut.

\section{Reproduksi RSA}

Merebaknya wacana komunisme nampaknya menyebabkan pemerintah Jokowi mengevaluasi diri. Bila diterus teruskan akan cenderung merugikan citranya sebagai presiden dan calon presiden berikutnya. Pihak yang meneguk keuntungan atas wacana tersebut adalah lawan politiknya, terutama kalangan Islam "kanan" yang mengusung komunisme sebagai bahan orasi aksi unjuk rasa. Karena itu, berikutnya pemerintah mereproduksi wacana wacana tandingan untuk meredam wacana komunisme. Para pengusung wacana anti komunisme diposisikan sebagai ancaman bagi NKRI, tidak Pancasilais, dan intoleran. Hal itu ditegaskan Pada kesempatan peringatan Hari Lahir Pancasila tanggal 1 Juni 2017, Jokowi melancarkan sejumlah wacana pendukung seperti: gotong royong, toleran, persatuan dan kesatuan bangsa, kebhinekaan, serta menyebut wacana ancaman seperti radikalisme dan terorisme (https://www. youtube.com/watch? $v=2 p 7$-taNanhU). Setelah itu Presiden menerbitkan Peraturan Presiden no.54 tahun 2017 yang berisi pembentukan Unit Kerja Presiden untuk Pembinaan Ideologi Pancasila. Kemudian Presiden menerbitkan Peraturan Pemerintah Pengganti Undang Undang (Perpu) No 2 tahun 2017 untuk menggantikan UU No.13 tahun 2013 tentang Organisasi Kemasyarakatan. Berdasarkan Perpu tersebut pemerintah membubarkan HTI (Hizbut tahrir Indonesia) karena dianggap berlandaskan bukan Pancasila.

Reproduksi wacana oleh apartus diikuti dengan gerakan yang sangat masih, baik di media massa maupun kegiatan kegiatan yang dilakukan oleh masyarakat seperti seminar, pengabdian masyarakat, dan mobilisasi komponen masyarakat (perguruan tinggi, pesantren, dan kantor kantor pemerintahan). Gerakan gerakan ini kemudian mereproduksi wacana bahaya paham dan ideology radikalisme.

Sebanyak 79 rektor universitas yang tersebar di 12 provinsi berkumpul di Universitas Mahendradatta, Denpasar, Bali pada Kamis (27/7/2017). Mereka menggelar focus group discussion (FGD) membahas cara mengantisipasi fenomena radikalisme dan terorisme (http://regional. kompas.com/read/2017/07/28/05160051/ bahas-radikalisme-79-rektor-berkumpul-dibali)

Aparatus Jokowi telah berhasil menciptakan situasi seolah olah di sekitar kita telah terjangkit paham radikal. Komunisme dan perilaku korupsi hilang dari wacana.

Tepatlah apa yang dikatakan Althusser bahwa ideology merupakan dialektika yang dikarakteristikkan kekuasaan yang tidak seimbang atau dominasi. Akhirnya Althusser meyakini bahwa ymbolt sebagai praktek ketimbang gagasan. Bila hal itu dilakukan oleh Negara, maka disebut represif state apparatus (RSA). Melalui perangkat ideology, Negara memaksa persepsi, nilai, dan tindakan masyarakat sama dengan yang dirumuskan atau dipersepsikannya. Dalam pandangan Althusser, idelogi kerap kali dipakai sebagai alat melanggengkan penindasan (Eriyanto, 2001: p.98). Alih alih bisa juga melanggengkan kekuasaan.

Melalui pendekatan RSA issu komunisme direproduksi menjadi issu radikalisme kemudian dikongkretkan sebagai "radikalisme adalah paham yang berusaha mengganti dasar Negara Pancasila dengan simbollain". Makna bahaya komunisme bergeser subjeknya dari pelaku dan penganut paham komunisme yang dikaitkan dengan peristiwa 30 September 1965 menjadi pelaku atau penganut paham yang hendak mengganti ymbolt Pancasila. Penyebar bahaya laten komunisme banyak didukung kalangan Islam kanan, sebagaimana menyebar melalui "youtube". Front Pembela Islam 
(FPI) dan organisasi lain sangat getal turun ke jalan menolak paham komunisme (www. youtube.com/watch?v=0VzHDonjbAo). Tercatat juga Prijanto (Wakil Gubernur Jakarta periode 2007-2012) mengatakan bila Jokowi Presiden, maka paham komunisme akan hidup lagi (www.youtube. $\mathrm{com} /$ watch? $\mathrm{v}=$ HN7eoySlkg4). Kalangan muda dari IAIN Jember juga mengaupload penolakannya terhadap komunisme (/www. youtube.com/watch?v=_CMSno52vYY). Juda Dewan Dakwah Islamiyah Indonesia menonjolkan ceramahnya Alfian Tanjung yang mengaitkan bahaya komunisme dengan maraknya imigran asal China (www.youtube.com/watch?v=dJSj2JaVtu4). Dengan mengetik kata kunci "komunisme" muncul ratusan video yang menolak komunisme di youtube. Diantara ormas Islam dan komunitas Islam yang paling bersemangat sesungguhnya ormas FPI, namun karena ormas ini sudah berlandaskan Pancasila, maka selamat dari pembubaran. Satu satunya yang bisa dipakai untuk memperkuat narasi "radikalisme dengan makna anti Pancasila" adalah ormas HTI. Dengan demikian HTI menjadi satu satunya korban dari RSA ini. Meskipun hanya satu ormas, sebagai narasi dapat dipakai untuk membangun wacana yang lebih luas sehingga menggeneralisir RSA sebagai fungsi sosialisasi ideology yang mengindektikkan diri kelompok yang loyak terhadap Negara NKRI.

Sejauh ini (hingga artikel ini diselesaikan) masing-masing kelompok ini tidak sampai konflik secara horizontal. Keduanya melanjutkan wacananya dengan meninggalkan sumber konfliknya. Pemerimtah meneruskan RSA-nya dengan perlahan lahan meninggalkan kata "komunisme" dan diganti dengan paham radikalisme, kemudian sekali-kali menjustifikasi dengan diksi "terorisme". Untuk menarik kalangan Islam kiri, RSA mengadopsi istilah "Islam Rahmatan lilalamin", "Islam Tengah", "Islam Nusantara", dan "Islam yang Menyejukkan". Sementara kalangan yang semula menggunakan issu komunisme memilih diam. Sejauh ini, diamnya kalangan Islam yang menolak komunisme masih belum nampak arah ke depannya. Dalam beberapa group di media sosial, kelompok ini mengganti tema diskusi komunisme menjadi "fitnah akhir zaman", "tanda tanda akhir zaman", "gerakan shalat subuh berjamah", dan lainnya yang nampak soft. Metamorfosis tematik dapat dimaknai sebagai upaya untuk tetap menjaga jejaring komunikasi di media yang dianggap tidak terintervensi oleh kekuasaan apparatus. Sehingga sel sel jejaring komunikasi yang tersapu oleh Undang Undang Ormas masih tetap dapat dijaga keberadaannya dan pada waktunya yang tepat dapat dihidupkan kembali. Waktu yang tepat menurut peneliti adalah saat pemilihan umum (pemilu) tahun 2019, pemilu untuk ymboltive dan Presiden.

\section{Analisis Kuasa atas Wacana}

Analisis lain yang menarik atas pisau bedah Faoclaut adalah tentang siapa tokoh tokoh yang memainkan wacana untuk menjaga sumber kekuasaannya. Pada arus besarnya (makro nasional) paling tidak ada empat tokoh yang berada di sekitar wacana tersebut, yakni:

Presiden Jokowi memainkan wacana komunisme untuk menjaga sumber dukungan dari kalangan nasionalis. Sehingga basis pemilih yang ingin dipelihara dari kalangan PDI-P, Hanura, Nasdem, dan PKB. Bila pun Jokowi ingin merelasikannya dengan kalangan Muslim, pilihannya pada Islam moderat. Resikonya Jokowi akan dijauhi oleh kalangan Islam garis kanan. Kedua, Prabowo Subianto. Prabowo sendiri tidak terlalu aktif memainkan wacana komunisme, tetapi menggunakan tokoh tokoh lapis keduanya, seperti Kiflan Zein dan Fadli Zon. Kelompok ini meririsan dengan pendukung partai Gerindra dan PKS. Sementara dari kalangan Muhammadiyah dan PAN memilih menolak komunisme tetapi dengan landai. Ketiga, Kapolri Tito Karnavian. Tokoh ini memegang peranan penting dalam menyelesaikan aksi demo penistaan agama yang bertajuk "Aksi 212", meskipun cenderung menolak demo tersebut tetapi sebagai pribadi dia berada di atas panggung bersama tokoh tokoh "Aksi 212". Dan Tito-lah yang berhasil membelah 
opini dari aksi penolakan penistaan agama menjadi "ancaman percobaan maker" yang dilakukan oleh tokoh lain seperti Ramhawati Soekarnoputri dan lain lain. Tindakan Polri ini saat ini dapat memecah opini public, sehingga issu media arus utama menjadi terbelah.

Yuzril Izha Mahendra selaku kuasa hukum Rachmawati Soekarnoputri mengatakan demikian :

"Penangkapan terhadap sejumlah pihak terduga aker oleh kepolisian diduga terkait dengan sejumlah pertemuan khusus dengan Rachmawati Soekarnoputri. Yusril mengatakan, pertemuan itu terjadi usai pertemuan terbuka di Universitas Bung Karno yang dihadiri oleh sejumlah tokoh aktivis. la berkata, pertemuan khusus itu diduga terkait dengan tuduhan kepolisian soal adanya rencana maker" (www.cnnindonesia.com/ nasional/20161202191617-20-177000/ yusril-penangkapan-rachmawatiterkait-pasca-rapat-di-ubk/)

Pada akhir Agustus tahun 2017, Tito menunaikan ibadah haji. Beritanya menyebar di media arus utama maupun media on-line. Setelah pulang haji, Tito ymbol lebih ramah terhadap kalangan Islam. Bahkan tidak pernah mewacanakan tentang radikalisme lagi. Dengan demikian, reproduksi komunisme dan radikalisme membangun ymbol Tito sebagai tokoh yang ramah, toleran, dan menangani persoalan secara taktis.

Keempat: Jendral TNI Gatot Nurmantyo. Gatotlah yang membuat wacana komunisme menjadi simulakral, berkembang biak dalam waktu cepat dalam area yang luas. Perintah Gatot untuk menonton film G 30 S/PKI menjadi viral dalam waktu yang lama. Gatot pun menjadi ymbol anti komunisme dan perilakunya lebih merepat ke kalangan Islam, terutama PKS.

Bila produksi wacana dan reproduksi wacana beserta turunannya terus bergulir hingga 2019, maka keempat tokoh inilah yang diuntungkan. Karena itu bila wacana dianggap sebagai representasi realitas, dalam politik sama halnya dengan realitas dukungan, dan pemilu menjadi instrument untuk meraup kekuasaan, maka sangat mungkin Jokowi dan Prabowo akan berhadap hadapan lagi sebagaimana Pilpres tahun 2014. Tito Karnavian akan digandeng oleh Jokowi sebagai Calon Wakil Presiden, namun bisa juga Jokowi menggandeng Gatot. Sedangkan Gatot lebih berpotensi digandeng Prabowo.

Beberapa reproduksi wacana Pilpres mencoba mendorong Gatot menjadi Capres sendiri. Menurut penelitian Vixvol center elektabilitas Jokowi memang masih unggul dari Prabowo tetapi tidak sampai 50\%. Itu berarti public membutuhkan tokoh lain di luar dua tokoh tersebut alias kuda hitam. Menurut survey ini tokoh yang dimaksud adalah Gatot Nurmantyo(http://www.portalislam.id/2017/10/voxpol-center-2019bukan-lagi-milik.html).

\section{E. KESIMPULAN}

Komunisme sebagai wacana berhasil membelah kekuatan politik antara yang mendukung dan menolak. Masing masing memproduksi wacana tersebut dengan berbagai reproduksi turunannya. Dalam level penyebar luasannya melalui media arus utama maupun media on-line wacana komunisme berubah menjadi "paham radikalisme". Reproduksi turunannya itu dipakai oleh RSA sebagai serangan balik, sehingga kelompok yang menolak paham komunisme secara tidak langsung mendapat stigma sebagai kelompok radikal. Kemudian ditambah dengan wacana "anti Pancasila" dan "Anti NKRI". Reproduksi wacana radikalisme bersifat lebih massif, dari segi menggunakan aparatur yang ada maupun melalui media arus utama, sehingga wacana komunisme berhasil ditenggelamkan atau ditinggal. Sebagai gantinya, pemerintah yang semula dituduh sebagai pendukung komunisme berhasil memukul balik lawan lawan politiknya dengan stigma radikalisme. Melalui logika Althusser, proses produksi dan reproduksi wacana seperti ini memperlihatkan kekuatan Negara yang dominan untuk mengeliminir 
wacana wacana yang tidak menguntungkan kridibilitasnya.

Sementara pada level relasi kuasa Foucault, wacana komunisme dapat memetakan individu atau lembaga yang berada di sekitarnya. Mereka yang mengendalikan wacana komunisme antara lain Joko Widodo, Prabowo Subianto, Tito Karnavian, dan Gatot Nurmantyo. Namun pada Agustus 2018, tokoh tokoh reproduksi wacana tersebut tidak diambil oleh Jokowi sebagai Calon Wapres dalam Pilpres 2019 disebabkan banyak factor yang membutuhkan penelitian lebih lanjut.
Kelak buah dari pemanfaatan wacana tersebut dapat dibuktikan dalam peta dukungan pada pemilu Presiden tahun 2019 dengan catatan wacana komunisme dan radikalisme ini tidak ditenggelamkan dengan wacana lain yang lebih memiliki daya magnitude.

Pada kubu Calon Presiden Prabowo Subianto nampaknya akan banyak mengembangkan issu ekonomi, mengingat politik identitas lebih melakat pada kubu Jokowi melalui kehadiran Ma'ruf Amin di dalamnya.

\section{DAFTAR PUSTAKA}

Abdullah, Taufik (eds). 2012. Malam Bencana 1965 Dalam Belitan Krisis Nasional Bagian II Konflik Lokal. Jakarta: Yayasan Pustaka Obor Indonesia.

Denny JA. 2006. 2006. Partai Politikpun Berguguran. Yogyakarta: LKiS

Dijk, Jan Van. 2012. The Network Society. California : SAGE Publications.

Eriyanto. 2000. Kekuasaan Otoriter: Dari Gerakan Penindasan Menuju Hegemoni. Yogyakarta: Insist Press.

Eriyanto. 2001. Analisis WacanaPengantar Analisis Teks Media. Yogyakarta: LKiS

Hermawan, Anang. 2011. Mix Methodology Dalam Penelitian Komunikas. Yogyakarta: ASPIKOM.

Ida, Rachmah. 2014. Metode Penelitian Studi Media dan Kajian Budaya. Jakarta: Prenada Media.

Jacob, Tengku. 2004. Tragedi Negara Kesatuan Kleptokratis Catatan di Senjakala. Jakarta: Yayasan Obor

Littlejohn, Stephen W (edt). 2009. Enclyclopedia of Communication Theory. California: SAGE Publication, Inc.

Lull, James. 1998. Media Komunikasi Kebudayaan Suatu Pendekatan Global. Jakarta: Yayasan Obor.

Mulyana, Deddy. 2012. Komunikasi Politik-Politik Komunikasi. Bandung: Rosdha Karya.

Panuju, Redi. 2002. Relasi Kuasa Negara,Media, dan Publik. Yogayakarta: Pustaka Pelajar.

Panuju, Redi. 2017. Sistem Penyiaran Indonesia. Jakarta : Kencana Prenada Mediagroup. Cet-2.

Panuju, Redi. 2017. Komunikasi Politik Jokowi: Antara Pencitraan dan Jejaring Politik. Jurnal Komunikatif. No 16 (2) 2017: 92-116. ISSN: 2597-6699

Yuliati, Dewi. 2000. Semaoen: Pers Bumi Putra dan Radikalisasi Sarekat Islam Semarang. Semarang: Yayasan Akikarya IKAPI dan The Ford Foundation dan Penerbit Bendera.

Simbolon, Parakitri T. 1998. Media Komunikasi Kebudayaan Suatu Pendekatan Global. Jakarta: Yayasan Obor. 
Siregar, Ashadi (eds). 1997. Ilusi Sebuah Kekuasaan. Surabaya: ISAI \& Ubaya.

Liddle, R.William. (1992). Partisipasi \& Partai Politik Indonesia pada Awal Orde Baru. Jakarta: Grafit. 